\title{
The hypotensive effect of Yoga's breathing exercises: A systematic review
}

\author{
Jeniffer Z. Brandani*, Julio Mizuno, Emmanuel G. Ciolac, Henrique L. Monteiro \\ São Paulo State University (Unesp), School of Sciences, Physical Education Department, Bauru, Brazil
}

\section{A R T I C L E I N F O}

Article history:

Received 19 April 2017

Accepted 8 May 2017

\section{Keywords:}

Cardiovascular diseases

Complementary therapies

Hypertension

\begin{abstract}
A B S T R A C T
The aim of this review was to evaluate the effect of pranayama (Yoga's breathing exercises) on BP and its applicability in the treatment of hypertension. Thirteen trials, assessing acute (eight studies) and chronic (five studies) BP response to pranayama were included. Significant BP reductions after pranayama were found in both acute $(2-10 \mathrm{mmHg}$ mean SBP reduction, $\mathrm{N}=5$ studies; $1 \mathrm{mmHg}$ mean DBP reduction, $\mathrm{N}=1$ study) and chronic studies (4-21 $\mathrm{mmHg}$ mean SBP reduction, $\mathrm{N}=3$ studies; $4-7 \mathrm{mmHg}$ mean $\mathrm{DBP}$ reduction, $\mathrm{N}=2$ studies). The pranayama's effect on $\mathrm{BP}$ were not robust against selection bias due to the low quality of studies. But, the lowering BP effect of pranayama is encouraging. The pranayama with slower rhythms and manipulation of the nostrils, mainly with breaths by the left, present better results when compared with the other types and should be the main pranayama applied when the goal is to reduce blood pressure especially in hypertensive patients.
\end{abstract}

๑) 2017 Elsevier Ltd. All rights reserved.

\section{Contents}

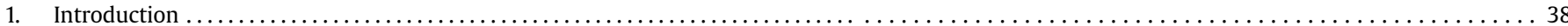

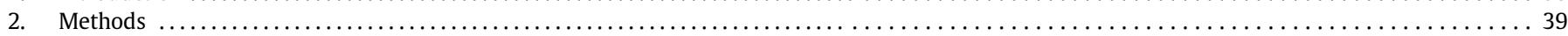

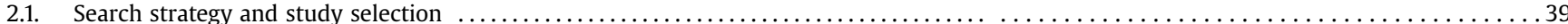

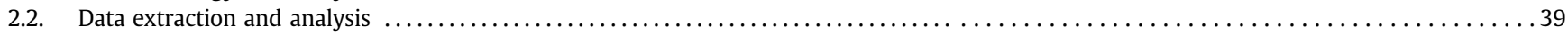

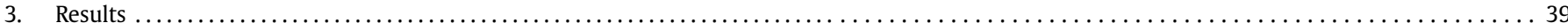

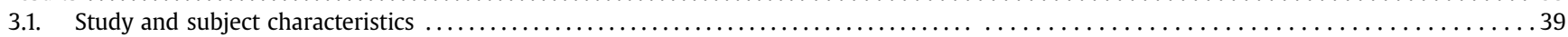

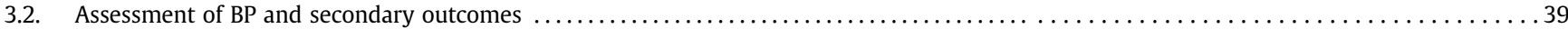

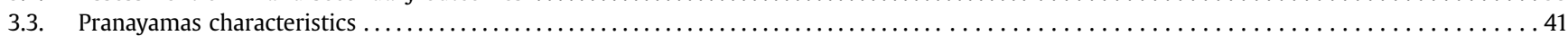

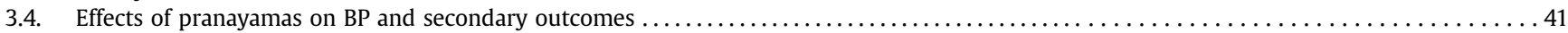

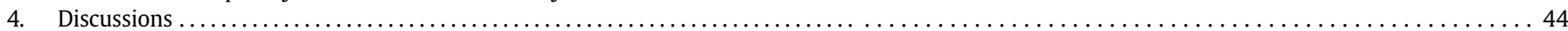

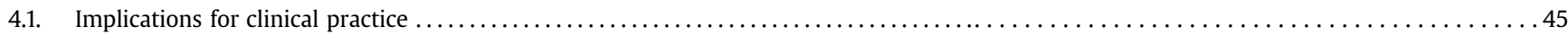

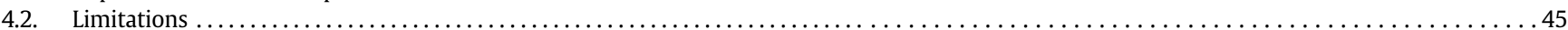

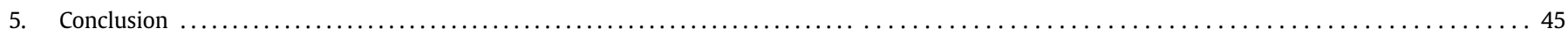

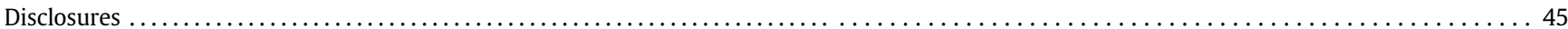

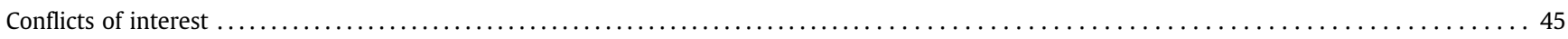

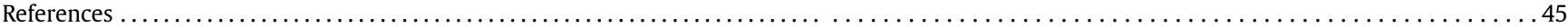

* Corresponding author. Universidade Estadual Paulista - UNESP, Departamento de Educação Física, Av. Engenheiro Luiz Edmundo Carrijo Coube 14-06, Bauru, São Paulo, 17033-360, Brazil. Tel.: +55 1431036082 .

E-mail addresses: jeniffer_brandani@yahoo.com.br(J.Z. Brandani), juliomizuno@ gmail.com (J. Mizuno), ciolac@fc.unesp.br (E.G. Ciolac), heu@fc.unesp.br (H.L. Monteiro).

\section{Introduction}

Hypertension is a highly prevalent disease worldwide and an important risk factor for stroke, coronary artery disease and organ failure [1]. In Brazil, nearlly $24.4 \%$ and $21.6 \%$ of adult women and men are hypertensive, respectively [2]. The regular practice of 
physical exercise is a well-established non-phamarcological treatment for hypertension [3-7]. Among the different types of exercise, there is increasing evidence suggesting a hypotensive effect of regular practice of Yoga [8-12].

In a broader context, Yoga includes theoretical and philosophical concepts (yamas and niyamas), body techniques (asanas), breathing exercises (pranayamas), concentration (dharana) and meditation [13]. Among these techniques, pranayamas (breathing exercises of varied time and pace that may be performed with or without air retention in the lungs) appears to have a better risk/benefit ratio for lowering blood pressure (BP) [14]. Moreover, pranayamas practice does not have costs with specific equipment and places, which may increase its applicability. The main mechanism for its lowering effect on BP appears to be the improvement in baroceptor sensitivity, which changes the autonomic balance with an increase in parasympathetic and decrease in sympathetic modulation [15,16].

Although there are systematic reviews and meta-analyzes supporting the hypotensive effects of Yoga $[14,17,18]$, the broad variety of techniques performed in each individual study (i.e. some studies use only one technique while others used two or more techniques) difficults the interpretation of pranaymas lowering BP effect. Therefore, the aim of this review was to evaluate the effect of pranayamas on BP and its applicability in the treatment of hypertension.

\section{Methods}

\subsection{Search strategy and study selection}

PubMed/Medline, Scopus and Bireme electronic databases were searched for articles about pranayamas effects on BP. Search was performed by crossing the terms 'yoga/Yoga', 'yogue/yogi', 'pranayama' or 'breathing' with 'blood pressure', 'hypertension' or 'systolic/diastolic BP'.

The present systematic review included only clinical trials, published between January 2006 and August 2016, that investigated the effect of pranayamas on BP in adult individuals (age $\geq 18$ ys), with or without comorbidities. There were no imposed sex or language restrictions. Because of the variability of existing breathing techniques, only explicitly labeled interventions with the term "Yoga" were included. Methodologic or observational (descriptive only) articles, studies with pranayamas associated with other intervention were not included. Clinical trials that did not have the full text available were also not included. Two independent reviewers (J. Z. B. and J. M.) performed the literature search and study assessment.

\subsection{Data extraction and analysis}

Data on study source, sample size, participant's characteristics (e.g. age, sex, baseline BP and physical activity levels, comorbidities ...), method used to measure BP, characteristics of breathing exercise (i.e. type, frequency and duration of breath, breath techinique) and control interventions (i.e. type, frequency and duration), outcomes and limitations of the included studies were extracted independently by two authors (J. Z. B. and J. M.). When there was discrepancy between reviewers, a third reviewer (H. L. M.) was consulted to solve the discrepancy. Methodological quality of included studies was assessed using the Physiotherapy Evidence Database (PEDro) scale (www.pedro.org.au). The results of the systematic review are presented descriptively (e.g. means, standard deviations, and minimum and maximum values).

\section{Results}

Electronic databases search identified 347 records. Title and abstract screening discharged 219 duplicates, 49 reviews, 43 with no full-text available, 10 with no BP assessment, five with nopranayamas intervention, one editorial and one experience report. Full text screening discharged one study with participants with age $<18$ years and three studies that pranyama was not the only intervention. Finally, thirteen articles assessing the acute (eight studies) [9,10,19-24] and chronic (five studies) [25-29] effects of pranayamas were included in this review (Fig. 1).

\subsection{Study and subject characteristics}

General description of each study included is shown in Table 1. Twelve studies were conducted in India and one in UK. Subjects with hypertension were included in six of them $[9,10,20,23,25,26]$. Eight studies assessed the acute effect of pranayamas (BP response to a single exercise session) $[9,10,19-24]$, which had a sample size ranging 20 to 90 participants (totaling 266 participants), and included only men [24,26], or both men and women $[9,10,19-21,23]$. Five studies assessed the chronic effect of pranayamas (BP response to an exercise program) [25-29], which had a sample size ranging 11 to 90 participants (totaling 239 participants), and included only men [28,29], and both men and women $[25,26]$ however, one study have no information about sex of participants [27].

Only three studies assessing the chronic effect of pranaymas were randomized controlled trial (RCT) $[23,27,28]$, and only one study assessing the pranaymas acute effect had a control intervention [24]. Finally, most studies were of poor quality. The median PEDro score was $\approx 3$, with a range from 1 to 7 (Table 2 ).

\subsection{Assessment of BP and secondary outcomes}

In the studies evaluating the acute effects of pranayamas, BP assessment was performed by means of semiautomatic noninvasive [9,10,20], continuous non-invasive [21,24], digital [19] and standard mercury sphygmomanometer $[22,23]$. In the studies

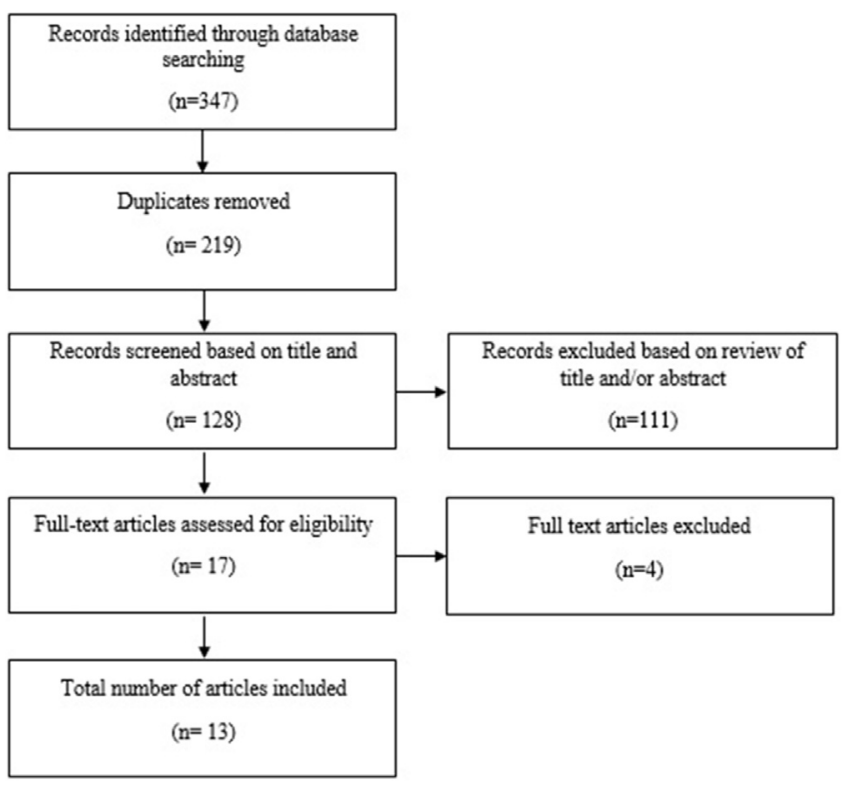

Fig. 1. Flowchart of the results of the literature search. 
Table 1

General characteristics of included studies.

\begin{tabular}{|c|c|c|c|c|c|}
\hline $\begin{array}{l}\text { Author, year and } \\
\text { country }\end{array}$ & Design of study & $\begin{array}{l}\text { Nunber/age/sex and characteristics of } \\
\text { participants }\end{array}$ & $\begin{array}{l}\text { Experimental intervention/ } \\
\text { Duration/ }\end{array}$ & $\begin{array}{l}\text { Control group/ } \\
\text { intervention }\end{array}$ & $\begin{array}{l}\text { Mesures of blood pressure/kind of } \\
\text { device }\end{array}$ \\
\hline $\begin{array}{l}\text { Adhana et al. (2013) } \\
\text { (India) [25] }\end{array}$ & 1 group & $\begin{array}{l}38 \text { adults }(8 \text { excluded }) / \text { men and women } \\
(20-50 \text { years }) / \text { recently diagnosed } \\
\text { hypertension }\end{array}$ & $\begin{array}{l}\text { Pranayama 2:1/twice a day for } 5-7 \mathrm{~min} \\
\text { for } 3 \text { months. }\end{array}$ & No control intervention & $\begin{array}{l}\text { A resting measure pre intervention and } \\
\text { weekly measures of BP/automated } \\
\text { digital } \\
\text { Sphygmomanometer }\end{array}$ \\
\hline $\begin{array}{l}\text { Bhavanani et al. (2011) } \\
\text { (India) [9] }\end{array}$ & 1 group & $\begin{array}{l}23 \text { adults }(11 \text { men }) / 55.13 \pm 1.54 \text { years/ } \\
\text { with hypertension }\end{array}$ & Sukha pranayama/5 min & No control intervention & $\begin{array}{l}\text { One measured pre and post } \\
\text { intervention/Semiautomatic }\end{array}$ \\
\hline $\begin{array}{l}\text { Bhavanani et al. }(2012)^{\mathrm{a}} \\
\text { (India) [10] }\end{array}$ & 1 group & $\begin{array}{l}22 \text { adults }(12 \text { men }) / 58,14 \pm 1,69 \text { years/ } \\
\text { with hypertension }\end{array}$ & Chandra Nadi Pranayama/5 min & No control intervention & $\begin{array}{l}\text { One measured pre and post } \\
\text { intervention/Semiautomatic }\end{array}$ \\
\hline $\begin{array}{l}\text { Bhavanani et al. }(2012)^{\mathrm{b}} \\
\text { (India) [19] }\end{array}$ & 1 group & $\begin{array}{l}29 \text { adults }(16 \text { men }) / 49,34 \pm 2,36 \text { years/ } \\
\text { with hypertension }\end{array}$ & Pranva Pranayama 1:3/5 min & No control intervention & $\begin{array}{l}\text { One measured pre and post } \\
\text { intervention/Digital }\end{array}$ \\
\hline $\begin{array}{l}\text { Bhavanani et al. (2014) } \\
\text { (India) [20] }\end{array}$ & 1 group & $\begin{array}{l}20 \text { adults }(13 \text { women }) / 34,10 \pm 13,62 \\
\text { years/8 healthy, } 12 \text { reported conditions } \\
\text { such as hypertension, hypothyroidism, } \\
\text { type } 2 \text { diabetes mellitus, polycystic } \\
\text { ovary syndrome, bipolar affective } \\
\text { disorder and others. }\end{array}$ & $\begin{array}{l}\text { Surya pranayama } v s \text {. chandra } \\
\text { pranayama vs. surya bhedana vs. } \\
\text { chandra bhedana } v s \text {. nadi shuddhi vs. } \\
\text { normal breathing } / 5 \text { min for each } \\
\text { pranayama ( } 6 \text { sessions) }\end{array}$ & No control intervention & $\begin{array}{l}\text { One measured pre and post } \\
\text { intervention/Semiautomatic }\end{array}$ \\
\hline $\begin{array}{l}\text { Critchley et al. (2015) } \\
\text { (Reino Unido) [21] }\end{array}$ & 1 group & $\begin{array}{l}\text { Twenty-three healthy volunteer } \\
\text { participants }(8 \text { women } 12 \text { men; } \\
34.5 \pm 10.4 \text { yrs })\end{array}$ & $\begin{array}{l}\text { Slow breathing and normal breathing } / 1 \\
\text { session } \approx 28 \mathrm{~min} \text {. }\end{array}$ & No control intervention & $\begin{array}{l}\text { Continuous monitoring/Non-invasive } \\
\text { monitor }\end{array}$ \\
\hline Goyal, 2014 (India) [26] & 2 groups & $\begin{array}{l}50 \text { adults with hypertension/ } \\
\text { Pranayama group }(n=25) \text { and Control } \\
\text { group }(n=25) / 20-50 \text { years/women } \\
\text { and men }\end{array}$ & $\begin{array}{l}\text { GP: Nadi shodana }+ \text { Chadar bhedi, } \\
\text { Bhramari + Omkar chanting } / 6 \\
\text { weeks } \approx 40 \mathrm{~min}\end{array}$ & GC: No intervention & $\begin{array}{l}\text { One measured pre and post } \\
\text { intervention/Standard } \\
\text { sphygmomanometer }\end{array}$ \\
\hline $\begin{array}{l}\text { Raghuraj et al. } \\
\text { (2008)(India) [22] }\end{array}$ & 1 group & 21 healthy men $/ 27,5 \pm 6,3$ years & $\begin{array}{l}\text { right, left, alternate nostril, breath } \\
\text { awareness and normal breathing/ } 5 \\
\text { sessions of } 40 \text { min }\end{array}$ & No control intervention & $\begin{array}{l}\text { One measured pre and post each } \\
\text { session/Manual }\end{array}$ \\
\hline $\begin{array}{l}\text { Sharma et al. (2013) } \\
\text { (India) [27] }\end{array}$ & $\begin{array}{l}\text { Randomized/3 } \\
\text { groups }\end{array}$ & $\begin{array}{l}90 \text { healthy subjects/without } \\
\text { information on sex/age between } 18 \text { and } \\
25 \text { years }\end{array}$ & $\begin{array}{l}\text { G1: Slow breathing; G2: Fast breathing/ } \\
30 \text { min a day, } 3 \text { times per week for } 12 \\
\text { weeks }\end{array}$ & GC: No intervention & $\begin{array}{l}\text { Three BP and HR recordings at } 1 \mathrm{~min} \\
\text { intervals were taken and the lowest of } \\
\text { these values was included for the } \\
\text { present study/Semi-automatic }\end{array}$ \\
\hline $\begin{array}{l}\text { Telles et al. (2013) } \\
\text { (India) [23] }\end{array}$ & $\begin{array}{l}\text { Randomized/ } \\
\text { Double Blinded/3 } \\
\text { groups }\end{array}$ & $\begin{array}{l}90 \text { adults }(60 \text { men }) / \text { with hypertension/ } \\
49.7 \pm 9.5 \text { years }\end{array}$ & $\begin{array}{l}\text { G1: Anuloma-villoma pranayama/G2: } \\
\text { breath awareness/10 min per session }\end{array}$ & $\begin{array}{l}\text { GC: reading, } 10 \text { min per } \\
\text { session }\end{array}$ & $\begin{array}{l}\text { One measured pre and post each } \\
\text { session/Standard mercury } \\
\text { sphygmomanometer }\end{array}$ \\
\hline $\begin{array}{l}\text { Telles et al. (2014) } \\
\text { (India) [24] }\end{array}$ & 2 groups & $\begin{array}{l}41 \text { healthy } \mathrm{men} / \mathrm{PG} \mathrm{n}=26(23.8 \pm 3.5 \\
\text { years }) \text { e } \mathrm{CG} \mathrm{n}=15(26.1 \pm 4.0 \text { years })\end{array}$ & $\begin{array}{l}\text { GP: alternate nostril yoga breathing or } \\
\text { anulom-vilom pranayama and (b) breath } \\
\text { awareness } / 2 \text { sessions } 25 \mathrm{~min}\end{array}$ & $\begin{array}{l}\text { GC: breathing } \\
\text { normally/1 session - } \\
25 \text { min }\end{array}$ & $\begin{array}{l}\text { Continuous monitoring/Non-invasive } \\
\text { monitor }\end{array}$ \\
\hline $\begin{array}{l}\text { Turankar et al. } \\
\text { (2013)(India) [28] }\end{array}$ & $\begin{array}{l}\text { Randomized, } 2 \\
\text { groups }\end{array}$ & $\begin{array}{l}11 \text { healthy males aged between } \\
(27.83 \pm 0.91 \text { years }) / \text { Pranayama group } \\
\mathrm{n}=6, \text { non-pranayama group } \mathrm{n}=5\end{array}$ & $\begin{array}{l}\text { PG: AnulomaViloma technique of } \\
\text { pranayama with Kumbhak (alternative } \\
\text { nostril breathing with breath holding)/ } \\
\text { two sessions of } 20 \\
\text { min each day for seven days }\end{array}$ & $\begin{array}{l}\text { CG: normal breathing/ } \\
\text { two sessions of } 20 \\
\text { min each day for seven } \\
\text { days }\end{array}$ & $\begin{array}{l}\text { Measuting on the end of all stages/ } \\
\text { Automatic BP measuring apparatus }\end{array}$ \\
\hline $\begin{array}{l}\text { Veerabhadrappa et al. } \\
\text { (2011) (India) [29] }\end{array}$ & 1 group & $\begin{array}{l}50 \text { healthy men/between } 18 \text { and } 25 \\
\text { years }\end{array}$ & $\begin{array}{l}\text { Mukh Bhastrika/30min a day, } 5 \text { times } \\
\text { per week for } 12 \text { weeks }\end{array}$ & No control intervention & $\begin{array}{l}\text { Two measured pre and post } \\
\text { intervention/Postural Maneuver } \\
\text { (supine-standing)/Automatic } \\
\text { non-invasive monitor. }\end{array}$ \\
\hline
\end{tabular}




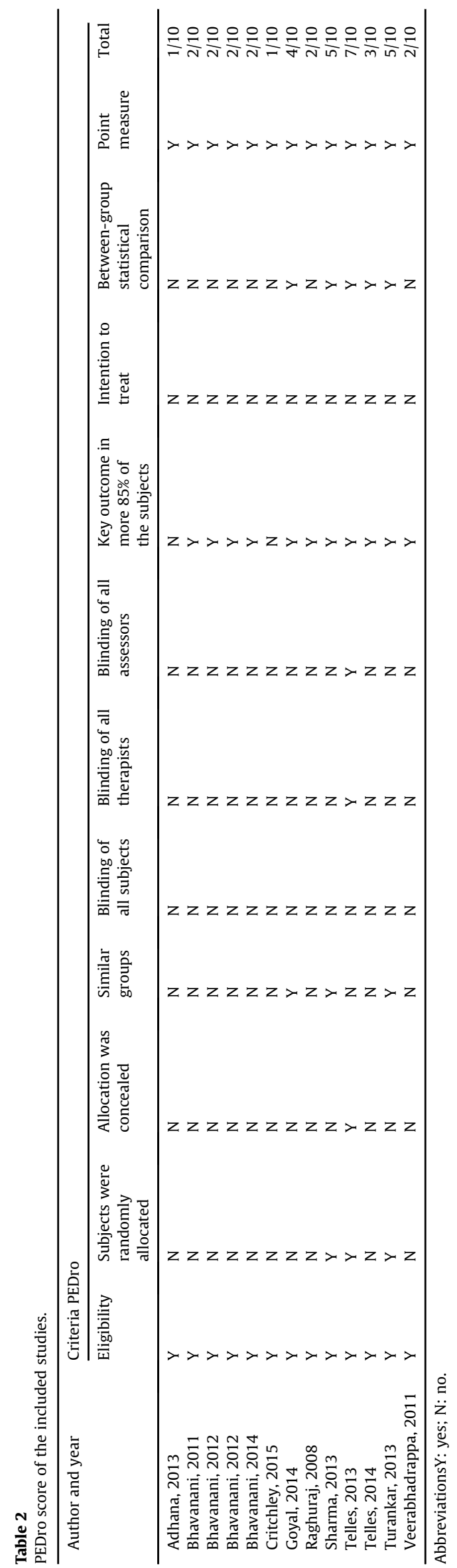

assessing pranayamas's chronic effects, BP assessment was performed by means of automatic non-invasive monitor [25,28,29], semiautomatic non-invasive [27] and standard sphygmomanometer [26]. Seven studies evaluated mean arterial pressure (MAP) $[9,10,19,20,22,27,28]$ by $\mathrm{MAP}=\mathrm{DBP}+1 / 3 \times \mathrm{PP}^{9,10,20,22}$, $\mathrm{MAP}=\mathrm{DBP}+\mathrm{PP} / 3^{27}, \mathrm{MAP}=[\mathrm{SBP} \times(1 / 3)+\mathrm{DBP} \times(2 / 3)]^{28}$ and one study didn't report [19]. Eleven studies assessed heart rate (HR) [9,10,19-22,25-29] by semi-automatic non-invasive BP monitor $[9,10,19,20,27]$, electrocardiogram [26,29], photoplethysmogrophic sensors [25], and Portapres [21]. The method for HR assessment was not reported in two studies [23,24]. Six studies presented values of rate pressure product (RPP; [RPP $=\mathrm{HR} \times \mathrm{SBP} /$ $100]^{9,10,19,20,27}$; or $\left[R P P=H R \times\right.$ SBP $\left.\times 10^{2}\right]$ ) [26]. Finally, five $[9,10,19,20,27]$ studies evaluated the double product (DP; [DP $=$ HR x MAP $/ 100]^{9,10,19,20}$ or $[\mathrm{DP}=\mathrm{HR} x \mathrm{MAP}]^{27}$ ).

\subsection{Pranayamas characteristics}

A detailed description of the pranayamas intervention characteristics for each study included in the present review is shown in Table 3. The studies assessing acute pranayamas effects $[9,10,19-24]$ had sessions lasting $5-40 \mathrm{~min}$. In the studies assessing chronic effects [25-29], the pranayamas' sessions lasted 5-40 min, and were performed for 1-12 weeks, with frequency of 3-7 days per week.

There was a great variation of interventions, with programs involving up to four types of pranayamas. All studies assessing acute effect of pranayamas used slow breathing [9,10,19-24], and five used panayamas with manipulation of the nostrils $[10,20,22-24]$. Among the studies evaluating the chronic effect of pranayamas, three used slow breathing $[25,26,28]$ (two with air retention $[26,28]$ ), one used rapid breathing with forced expiration [29], one used both slow and rapid breathing with forced expiration [27], and three studies used pranayamas with manipulation of the nostrils [26-28].

\subsection{Effects of pranayamas on BP and secondary outcomes}

The main effects of pranayamas on BP and secondary outcomes of each study are shown in Table 4. All studies with hypertensive subjects showed that pranayamas were effective to acutelly reduce systolic BP (mean BP reduction from 2 to $10 \mathrm{mmHg}$ ) [9,10,19,23]; however, the diastolic BP was reduced only in one studies [23] and after only one type of pranayama (mean BP reduction $1 \mathrm{mmHg}$ ). In normotensive subjects, two studies showed systolic BP reduction after an acute pranayamas session [21,24], and one study showed no effects on $\mathrm{BP}^{22}$, for diastolic BP one study showed reduces [22] (mean BP reducion $1 \mathrm{mmHg}$ ). Finally, one study with subjects with different chronic diseases showed a varied acute BP response (mean BP reduction from 1 to $4 \mathrm{mmHg}$ ) according to the pranayamas performed [20].

Among the studies assessing the chronic effects of pranayamas, systolic BP was reduced in all studies with hypertensive subjects $[25,26]$ (mean BP reduction from 12 to 21). However, in the studies with normotensive subjects, systolic BP was reduced in one [29] (mean BP reducion of $4 \mathrm{mmHg}$ ), while two studies showed no effects of pranayamas on $\mathrm{BP}^{27,28}$, the diastolic $\mathrm{BP}$ was reduced only in two studies [25,27], one with hypertensive and other with normotensive subjects, respectively (mean BP reduction 4-7 $\mathrm{mmHg}$ ).

HR was reduced in four studies assessing the chronic [25-27,29] and three acute $[9,10,19]$ effects of pranayamas. DP was reduced only in one chronic study [27] and three acute [9,10,19] and RPP reduce in two chronic studies $[26,27]$ and three acutes $[9,10,19]$. 
Table 3

Details about interventions of Yoga.

\begin{tabular}{|c|c|}
\hline Author, year and country & Details about the pranayamas \\
\hline Adhana et al. (2013) (India) [25] & $\begin{array}{l}\text { Subjects were guided by the investigator, to do } 2: 1 \text { breathing, maintaining respiratory rate of around } 6 \text { per minute. The } 2: 1 \\
\text { breathing is a type of yogic breathing technique in which exhalation is twice of inhalation. Subjects was asked to inhale while } \\
\text { counting } 1,2,3,4 \text { and exhale while counting } 1,2,3,4,5,6,7,8 \text {. There was no pause between inhalation and exhalation. }\end{array}$ \\
\hline Bhavanani et al. (2011) (India) [9] & $\begin{array}{l}\text { The pranayama was done through both nostrils in a calm and regular manner with a conscious effort to use the lower, middle, } \\
\text { and upper parts of the lungs in a sequential manner for both inhalation and exhalation. Participants were instructed to breathe in } \\
\text { and out for an equal count of } 5 \text { that was given by the instructor using a stopwatch. The instructor called out counts at the rate of } 6 \\
\text { breaths/min for the entire duration of } 5 \mathrm{~min} \text {. }\end{array}$ \\
\hline
\end{tabular}

Bhavanani et al. (2012) ${ }^{\mathrm{a}}$ (India) [10] The subjects were instructed to perform nasika mudra with their right hand, by touching the tip of their index finger to the base of their thumb. The right thumb was then used to close their right nostril with gentle pressure. The pranayama was then performed through the unblocked left nostril in a calm and regular manner with a conscious effort to use low, mid and upper parts of the lungs in a sequential manner for both inspiration and expiration. Subjects were instructed to breathe in and out for an equal count of 5 that was given by the instructor throughout the period in tune with a stop watch. A regularity of counts at the rate of 6 breaths/min (BPM) was maintained by the instructor for the entire duration of nearly 5 min taken to complete 27 rounds of CNP.

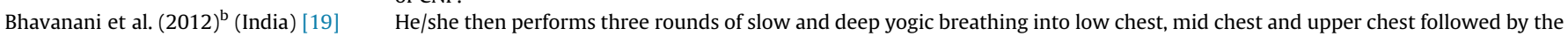
prolonged audible rendition of the akara, ukara and pseudo nada (Aaa, Uuu and Mmm sounds) respectively during exhalation phase. Following this, he/she performs three rounds of the complete yogic breathing (mahat yoga pranayama) technique with an audible rendition of omkara nada (AUM sound) during exhalation phase. The time taken for the exhalation with nada is approximately three times the time taken for each inhalation, thus maintaining a ratio of 1:3.

Bhavanani et al. (2014) (India) [20] Right UNB (SN) using nasika mudra wherein the ring finger was used to occlude left nostril by pressing on the outside of the nostril; Left UNB (CN) using nasika mudra wherein the thumb was used to occlude right nostril by pressing on the outside of the nostril; Breathing in through right nostril and out through the left (SB) using nasika mudra to regulate flow through respective nostrils; Breathing in through left nostril and out through the right $(\mathrm{CB})$ using nasika mudra to regulate flow through respective nostrils; Breathing in through left nostril and out through right followed by breathing in through right and out through left (NS) using nasika mudra to regulate flow through respective nostrils.

The main experimental session was undertaken over a continuous period ( 26.5 minutes-27.5 min, depending on seudo

Critchley et al. (2015)

(Reino Unido) [21] randomized order, see below), during which time the participant was prompted, over blocks of one minute either to breath at their own pace (unpaced), to breath slowly (slow paced), or to breath more rapidly (regular paced-approximating the normal supine breathing rate of most participants). Instructions were given as auditory cues at the onset of each block and throughout the paced breathing at the target rate ('breathe in', 'breathe out'). The participant also heard timing tones every second throughout each block.

Goyal, 2014 (India) [26]

Nadi-shodhana pranayama: Patient was instructed to use right thumb for right nostril and right third finger for left nostril. He was told to close the right nostril and inhale deeply through left nostril to the count of 4 . Then he was told to block both nostrils and hold the breath for 2 counts. This was followed by blocking of the left nostril and exhalation through the right nostril to the count of 4 . This act was repeated with the other nostril also. The time duration was at least 2 min at first, progressively increasing the duration up to $10 \mathrm{~min}$. Chandar Bhedi pranayama: The patient was asked to close the right nostril, inhale through the left nostril. Then he was told to close the left nostril and exhale through the right nostril without any pause. Time duration was at least for $2 \mathrm{~min}$ at first, progressively increasing the duration up to $10 \mathrm{~min}$. Bhramari pranayama: The patient was asked to close eyes with four fingers over each eye and thumbs blocking the ears. Then he was told to inhale deeply through both nostrils and with the mouth closed exhale through both the nostrils producing a continuous humming sound until the exhalation has exhausted. This was repeated for 10 cycles. Omkar chanting: The patient was asked to inhale deeply with both nostrils followed by a loud chanting of sound of omkar from the mouth during exhalation in the ratio of a: 0 ; ma as $1: 4 ; 2$. This was repeated for 10 cycles.

Raghuraj et al. (2008)(India) [22] There were three yoga breathing (pranayama) sessions and two control sessions one of breath awareness (BAW) and the other of normal breathing (CTL) given to each subject. The five practices are described below. (1) Right nostril yoga breathing (RNYB) or Suryanuloma viloma pranayama practice involves breathing exclusively in and out through the right nostril while the left nostril is gently occluded. (2) Left nostril yoga breathing (LNYB) or Chandra anuloma viloma pranayama practice involves breathing through the left nostril exclusively while the right nostril is occluded. (3) Alternate nostril yoga breathing (ANYB) or Nadisuddhi pranayama practice involves breathing through left and right nostrils alternately. Throughout these practices the awareness is directed to the breath and breathing. During breath awareness, the participants maintained awareness of the breath without manipulation of the nostrils (Visweswaraiah and Telles 2004). During the normal breathing session the participants sat at ease without specific instructions about their breathing. In the three nostril manipulating pranayamas the thumb and the ring finger of the right hand were used to manipulate or occlude the nostrils.

1. Fast Pranayama: Each cycle ( 6 min) consisted of practicing 1 min of Kapalabhati, Bhastrika and Kukkriya pranayama interspersed with $1 \mathrm{~min}$ of rest between each pranayama. Subjects were asked to complete 3 or more cycles in each session. Kapalabhati Pranayama: The subjects were instructed to sit in Vajrasana and to forcefully expel all of the air from the lungs while pushing the abdominal diaphragm upwards. The expulsion is active but the inhalation is passive. Subjects rapidly breathed out actively and inhaled passively through both nostrils. Bhastrika Pranayama: In this, emphasis is given to thoracic (not abdominal) breathing activity. Subjects were instructed to take deep inspiration followed by rapid expulsion of breath following one another in rapid succession. After 10 expulsions, the final expulsion is followed by the deepest possible inhalation. Breath is suspended as long as it can be done with comfort. Deepest possible exhalation is done very slowly. This completes one round of Bhastrika. Kukkriya Pranayam: To perform this dog pant like breathing technique, the subject sat in Vajrasana with both palms on the ground in front with wrists touching knees and fingers pointing forward. The mouth was opened wide and the tongue pushed out as far as possible. They then breathed in and out at a rapid rate with their tongue hanging out of their mouth. After 10 or 15 rounds they relaxed back into Vajrasana. 2. Slow pranayama: Each round ( $7 \mathrm{~min}$ ) of session consisted of practicing $2 \mathrm{~min}$ of Nadishodhana, Pranava and Savitri pranayama interspersed with $1 \mathrm{~min}$ of rest between each pranayama done in comfortable posture (sukhasana). Nadishodhana Pranayama: This is slow, rhythmic, alternate nostril breathing. One round consisted of inhaling through one nostril, exhaling through other nostril and repeating the same procedure through other nostril. Savitri Pranayama is a slow, deep and rhythmic breathing, each cycle having a ratio of 2:1:2:1 between inspiration (purak), heldin breath (kumbhak), expiration (rechak), and held out breath (shunyak) phases of the respiratory cycle. Each lobular segment of the lungs was filled and a six count was used for inspiration and expiration, with a three count for the retained breaths $(6 \times 3 \times 6 \times 3)$. Pranava Pranayama is slow, deep and rhythmic breathing where emphasis is placed on making the sound AAA, UUU and MMM while breathing out for duration of 2-3 times the duration of the inhaled breath. It is a four part technique 
Table 3 (continued)

\begin{tabular}{|c|c|}
\hline Author, year and country & Details about the pranayamas \\
\hline & $\begin{array}{l}\text { consisting of Adham Pranayama (lower chest breathing with the sound of AAA), Madhyam Pranayama (midchest breathing with } \\
\text { the sound of UUU), Adhyam Pranayama (upper chest breathing with the sound of MMM) and then the union of the earlier three } \\
\text { parts in a complete yogic breath known as Mahat Yoga Pranayama with the sound of AAA, UUU and MMM. }\end{array}$ \\
\hline Telles et al. (2013) (India) [23] & $\begin{array}{l}\text { Anulomaviloma pranayama (ANYB) involves breathing through left and right nostrils alternately. In this practice the thumb and } \\
\text { the ring finger of the right hand were used to manipulate or occlude the nostrils. The ANYB did not include breath retention. } \\
\text { Breath awareness (control session): During breath awareness, the participants maintained awareness of the breath without } \\
\text { manipulation of the nostrils. The participants' attention was directed to the movement of air into and out of their nostrils. They } \\
\text { also attempted to be aware of the air as it moved through their nasal passage. }\end{array}$ \\
\hline Telles et al. (2014) (India) [24] & $\begin{array}{l}\text { Alternate nostril yoga breathing (ANYB): the participants practiced alternate nostril yoga breathing which involves breathing } \\
\text { through both nostrils alternately without retention of the breath. The participants used the thumb and ring finger of the right } \\
\text { hand to manipulate the nostrils. The breathing practice begins by exhaling through the left nostril with the right nostril } \\
\text { occluded; then inhaling through the left nostril; followed by exhaling through the right nostril with the left nostril occluded; } \\
\text { then inhaling through the right nostril and exhaling through the left nostril. Breath awareness: the participants were asked to be } \\
\text { attentive to their breath during inhalation and exhalation without trying to modify their breath. }\end{array}$ \\
\hline Turankar et al. (2013)(India) [28] & $\begin{array}{l}\text { Slow breathing was done by sitting on the ground in Sukhasana (crossed leg with cervical and lumbar spine extended, arms } \\
\text { pronated and extended, wrists placed on knees, and fist closed), in an ambient, wellventilated, quiet room, at room temperature; } \\
\text { it was ensured that the subjects had no nasal obstruction. The subjects of the Pranayama group were trained in the } \\
\text { AnulomaViloma technique of pranayama with Kumbhak (alternative nostril breathing with breath holding). The subjects were } \\
\text { asked to breathe in through the left nostril over a period of } 6 \mathrm{~s} \text {, hold their breath for } 6 \mathrm{~s} \text { with both nostrils closed, and then to } \\
\text { exhale through the right nostril over a period of } 6 \mathrm{~s} \text {. }\end{array}$ \\
\hline Veerabhadrappa et al. (2011) (India) [29] & $\begin{array}{l}\text { Sit on padmasana. Keep the body, neck and head erect. Close the mouth. Inhale and exhale quickly ten times like the bellows of } \\
\text { the blacksmith i.e.,with hissing sound. Start with rapid expulsion of breath following one another in rapid succession. After ten } \\
\text { expulsions, the final expulsion is followed by the deepest possible inhalation. Breath is suspended as long as it can be done with } \\
\text { comfort. Deepest possible exhalation is done very slowly. This completes one round of Bhastrika. Rest a while after one round is } \\
\text { over by taking a few normal breaths. Start with the next round. Practice up to three rounds. After completion of Bhastrika } \\
\text { training for } 12 \text { weeks, there were no dropouts from the training session. The subjects were again subjected to the tests described } \\
\text { above, individually. }\end{array}$ \\
\hline
\end{tabular}

Table 4

Main results on blood pressure variables, other cardiovascular parameters and the conclusions of the studies assessed.

Author, year and Results Conclusion

Adhana et al. (2013)

(India) [25]
Adhana et al. (20

(India) [9]

Bhavanani et al. $(2012)^{\mathrm{a}}$ (India) [10]

Bhavanani et al. $(2012)^{\mathrm{b}}$ (India) [19]

Bhavanani et al. (2014)

(India) [20]
SBP $126.86 \pm 3.03$ vs. $124.07 \pm 3.09 \mathrm{mmHg}(\mathrm{p}<0.05) / \mathrm{HR}$

$75.24 \pm 2.34$ vs. $72.96 \pm 2.22$ beats $/ \mathrm{min}(\mathrm{p}<0.01) / \mathrm{DP}$

$69.07 \pm 2.75$ vs. $66.26 \pm 2.65$ units $(\mathrm{p}<0.01)$.

SBP $149 \pm 10$ vs. $137 \pm 8 \mathrm{mmHg}(\mathrm{p}<0.001) ;$ DBP $96 \pm 6$ vs. $89 \pm 4 \mathrm{mmHg}(\mathrm{p}<0.001)$; HR 84 vs. $79 \pm 3$ beats/min ( $<<0.001)$; RR $20 \pm 2$ vs. $17 \pm 2$ breaths/min $(\mathrm{p}<0.001)$.

SBP $134,68 \pm 3,17$ vs. $130,27 \pm 3,16 \mathrm{mmHg}(\mathrm{p}=0.001) / \mathrm{DBP}$ $78.77 \pm 1.74$ vs. $78.05 \pm 1.89 \mathrm{mmHg}(\mathrm{n} /$ dif $)$ HR $75,77 \pm 3,15$ vs. $73,45 \pm 3,12$ beats $/ \min (\mathrm{p}<0.001)$

SBP: $\Delta \%$ de Nadi Shuddhi $(-5,04 \pm 4,97)$ diferente from NB $(-0,90 \pm 5,05)$, surya bhedana $(1,23 \pm 5,33)$ and surya nadi $(1,49 \pm 5,17) / \mathrm{DBP}:$ Surya Bhedana $(4,17 \pm 6,46)$ different from chandra Bhedana $(2,42 \pm 6,94)$ and Chandra Nadi $(-2,05 \pm 7,59) /$ HR: $\Delta \%$ de Surya Bhedana $(2,22 \pm 6,42)$ statistically different from Chandra bhedana $(-4,61 \pm 5,99)$ and Chandra Nadi $(-4,78 \pm 7,17)$.
"2:1 yogic breathing technique like other breathing techniques causes a change in body physiology by altering various parameters that are governed by the autonomic nervous system. Since stress is one of the most important precipitating factors of essential hypertension, practice of 2:1 breathing can be helpful in patients of essential hypertension by lowering of blood pressure directly and also reducing stress levels in the body."

"We conclude that sukha pranayama when performed at the rate of 6 breaths/min is effective in reducing heart rate and blood pressure in hypertensive patients after just 5 min of practice. This finding has potential therapeutic applications in day-to-day as well as clinical situations where blood pressure needs to be brought down quickly. It is simple, cost-effective, and may be added to the management protocol for hypertensive patients in addition to the regular medical management of such situations."

"It is concluded that CNP is effective in reducing HR and SBP in hypertensive patients on regular standard medical management ... This may be due to a normalization of autonomic cardiovascular rhythms with increased vagal modulation and/or decreased sympathetic activity along with improvement in baroreflex sensitivity."

"It is concluded that the practice of pranava pranayama is effective in reducing HR and SBP in hypertensive patients. This may be due to a normalization of autonomic cardiovascular rhythms as a result of increased vagal modulation and/or decreased sympathetic activity and improved baroreflex sensitivity along with an augmentation of endogenous NO production."

"We conclude that right and left yogic UNB and ANB techniques have differential physiological effects. Right nostril initiated UNB and ANB techniques induce a state of arousal through sympathetic activation and/through increased ascending reticular activity and/or by central action at the primary thalamocortical level. On the other hand, left nostril initiated UNB and ANB techniques delay reactivity of the subjects by inducing a sense of inert lethargy and may induce a state of parasympathetic dominance as seen in CV parameters."

(continued on next page) 
Table 4 (continued)

\begin{tabular}{|c|c|c|}
\hline $\begin{array}{l}\text { Author, year and } \\
\text { country }\end{array}$ & Results & Conclusion \\
\hline $\begin{array}{l}\text { Critchley et al. (2015) } \\
\text { (Reino Unido) [21] }\end{array}$ & Values not shown/But no significant difference & $\begin{array}{l}\text { “... The correlates of respiratory change, along mid and dorsal } \\
\text { brainstem, thalamus and cortex and highlight the primacy of } \\
\text { ventilation to the representation and motor control of } \\
\text { breathing, particularly when engaged in controlled slow } \\
\text { breathing ..." }\end{array}$ \\
\hline Goyal, 2014 (India) [26] & $\begin{array}{l}\text { SBP: CG } 144 \pm 1.4 \text { vs. } 141 \pm 2,4 \mathrm{mmHg}(\mathrm{n} / \mathrm{dif}) ; \mathrm{PG} 148 \pm 1,6 \text { vs. } \\
127 \pm 2,4 \mathrm{mmHg}(\mathrm{p}<0.001) / \mathrm{HR}: \mathrm{CG} 95 \pm 2,7 \text { vs. } 80 \pm 2.44 \text { beats } / \\
\min (\mathrm{p}<0.001) ; \mathrm{PG} 95 \pm 1.79 \text { vs. } 76 \pm 1,96 \text { beats } / \mathrm{min}(\mathrm{p}<0.001)\end{array}$ & $\begin{array}{l}\text { "The pranayama produces relaxed state and in this state } \\
\text { parasympathetic activity overrides sympathetic activity. Hence, } \\
\text { addition of pranayama can be a useful addition to } \\
\text { antihypertensive drugs for better control of hypertension in } \\
\text { mild hypertensives." }\end{array}$ \\
\hline $\begin{array}{l}\text { Raghuraj et al. } \\
\qquad(2008) \text { (India) [22] }\end{array}$ & $\begin{array}{l}\text { RNYB: SBP } 110.57 \pm 6.52 \text { vs. } 116.67 \pm 5.41 \mathrm{mmHg}(\mathrm{p}<0.001) \\
\text { DBP } 72.67 \pm 5.30 \text { vs. } 76.00 \pm 5.02 \mathrm{mmHg}(\mathrm{p}<0.001) ; \mathrm{HR} \\
74.20 \pm 9.69 \text { vs. } 77.20 \pm 11.04 \text { beats } / \mathrm{min}(\mathrm{n} / \mathrm{dif}) / \mathrm{LNYB}: \mathrm{SBP} \\
110.38 \pm 6.53 \text { vs. } 106.19 \pm 6.51 \mathrm{mmHg}(\mathrm{p}<0.01) ; \mathrm{DBP} \\
72.76 \pm 4.88 \text { vs. } 71.62 \pm 4.67 \mathrm{mmHg}(\mathrm{n} / \mathrm{dif}) ; \mathrm{HR} 73.5 \pm 8.25 \text { vs. } \\
77.76 \pm 11.05 \text { beats } / \mathrm{min}(\mathrm{p}<0.05) / \mathrm{ANYB}: \mathrm{SBP} 109.81 \pm 6.19 v s\end{array}$ & $\begin{array}{l}\text { "Hence, the physiological effects of yoga breathing practices on } \\
\text { autonomic activity in conditions affecting autonomic balance ... } \\
\text { Hence, unilateral nostril yoga breathing practices appear to } \\
\text { influence the blood pressure in different ways. These effects } \\
\text { suggest possible therapeutic applications" }\end{array}$ \\
\hline
\end{tabular}

$77.76 \pm 11.05$ beats $/ \mathrm{min}(\mathrm{p}<0.05) /$ ANYB: SBP $109.81 \pm 6.19 v \mathrm{~s}$

$108.67 \pm 6.43 \mathrm{mmHg}(\mathrm{p}<0.05) ; \mathrm{DBP} 73.05 \pm 4.27 v s$.

$72.38+3.98 \mathrm{mmHg}(\mathrm{p}<0.05) ; \mathrm{HR} 75.78+9.11 v s$.

$80.61 \pm 10.61$ beats $/ \mathrm{min}(\mathrm{p}<0.05) /$ BAW: SBP $111.33 \pm 5.88 v s$.

$111.24 \pm 6.23 \mathrm{mmHg}(\mathrm{n} /$ dif $) ;$ DBP $72.67 \pm 4.49$ vs.

$72.48 \pm 4.51 \mathrm{mmHg}(\mathrm{n} /$ dif $) ; \mathrm{HR} 72.98 \pm 9.01$ vs. $74.98 \pm 8.12$

beats/min (n/dif)/NB: SBP $112.48 \pm 6.84$ vs. $112.19 \pm 6.60 \mathrm{mmHg}$ (n/dif); DBP $73.05 \pm 4.59$ vs. $72.19 \pm 4.47 \mathrm{mmHg}(\mathrm{p}<0.05) ; \mathrm{HR}$ $78.13 \pm 8.48$ vs. $77.30 \pm 7.35$ beats $/ \mathrm{min}(\mathrm{n} / \mathrm{dif})$.

Sharma et al. (2013)

(India) [27]

Gfast: SBP $114.36 \pm 10.86$ vs. $112.30 \pm 8.82 \mathrm{mmHg}$ (n/dif); DBP

$75.80 \pm 7.16$ vs. $74.16 \pm 6.80 \mathrm{mmHg}$ (n/dif); HR $76.83 \pm 5.41$ vs $75.73 \pm 4.89$ beats/min (n/dif)/Gslow: SBP $116.26 \pm 9.15$ vs.

$114.36 \pm 7.14 \mathrm{mmHg}(\mathrm{n} /$ dif $) ;$ DBP $74.30 \pm 7.40 v s$.

$70.16 \pm 4.48 \mathrm{mmHg}(\mathrm{p}<0.05) ; \mathrm{HR} 76.60 \pm 5.15 v s$

$73.66 \pm 3.90$ beats $/ \mathrm{min}(\mathrm{p}<0.001) ; / C G:$ SBP $115.06 \pm 8.75$ vs.

$113.50 \pm 8,26 \mathrm{mmHg}(\mathrm{n} / \mathrm{dif}) ; \mathrm{DBP} 73.33 \pm 5,35 v s$.

$74.10 \pm 4,18 \mathrm{mmHg}(\mathrm{n} / \mathrm{dif}) ; \mathrm{HR} 77.70 \pm 5.73$ vs. $76.83 \pm 4,59$

beats/min ( $\mathrm{n} / \mathrm{dif})$.

Telles et al. (2013) ANYB: SBP $133,67+14,26$ vs. $128,00 \pm 10,64 \mathrm{mmHg}(\mathrm{p}<0.001)$;

(India) [23]

DBP $85,67 \pm 8,58$ vs. $84,33 \pm 7,28 \mathrm{mmHg}(\mathrm{p}<0,05) / \mathrm{BAW}: \mathrm{SBP}$

$130.67 \pm 16.39$ vs. $127.2 \pm 13.72 \mathrm{mmHg}(\mathrm{p}<0.05) ; \mathrm{DBP}$

$84.33 \pm 10.73$ vs. $83.73 \pm 9.26 \mathrm{mmHg}(\mathrm{n} /$ dif $) / C G:$ SBP

$140.83 \pm 14.22$ vs. $139.53 \pm 18.65 \mathrm{mmHg}$ (n/dif); DBP

$81.20 \pm 9.42$ vs. $81.33 \pm 9.37 \mathrm{mmHg}(\mathrm{n} /$ dif $)$. ANYB group was

different from CG.

Telles et al. (2014)

(India) [24]

PG: ANYB SBP $119.8 \pm 9.2$ vs. $116.8 \pm 14.5 \mathrm{mmHg}$ (n/dif); DBP

$73.9 \pm 7.3$ vs. $73.1 \pm 8.8 \mathrm{mmHg}(\mathrm{n} / \mathrm{dif}) /$ BAW SBP $118.3 \pm 10.4 v s$.

$117.3 \pm 13.0 \mathrm{mmHg}(\mathrm{n} /$ dif $)$ DBP $75.3 \pm 6.2$ vs. $74.6 \pm 7.0 \mathrm{mmHg}$

(n/dif)/CG: SBP $118.7 \pm 11.9$ vs. $118.8 \pm 15.1 \mathrm{mmHg}$ (n/dif) DBP

$73.8 \pm 1.9$ vs. $72.7 \pm 11.6 \mathrm{mmHg}(\mathrm{n} / \mathrm{dif})$.

Turankar et al.

GP: SBP $118.7+7.26$ vs. $118.5+2.26 \mathrm{mmHg}$ (n/dif); DBP

(2013)(India) [28]

$67.67 \pm 9.89$ vs. $71.67 \pm 7.03 \mathrm{mmHg}(\mathrm{n} / \mathrm{dif}) ; \mathrm{HR} 77.17 \pm 9.43$

beats/min $(\mathrm{p}<0.05) / \mathrm{CG}$ : SBP $120.40 \pm 8.87 \mathrm{vs}$.

$123.00 \pm 10.39 \mathrm{mmHg}(\mathrm{n} / \mathrm{dif}) ;$ DBP $74.20 \pm 6.87 v s$

$71.80 \pm 1.08 \mathrm{mmHg}(\mathrm{n} / \mathrm{dif})$.

Supine SBP $112,08 \pm 8,99$ vs. $108,16 \pm 7,77 \mathrm{mmHg}(\mathrm{p}<0.001) /$

Veerabhadrappa et al.

(2011) (India) [29]

Standing SBP $106,88 \pm 9,98$ vs. $104,56 \pm 7,93 \mathrm{mHg}(\mathrm{p}<0,01) /$

HRrest $73.3 \pm 11.01$ vs. $59.9 \pm 10.06$ beats $/ \mathrm{min}(\mathrm{p}<0.001) /$

Difference $5.40 \pm 2.86 v s .3 .56 \pm 2.62 \mathrm{mmHg}(\mathrm{p}<0.001)$.

“... significant benefit on physiological parameters is seen in only subjects practicing slow pranayama. Since the results on perceived stress are comparable, slow pranayamas can be given to subjects in all age groups (both young and old) whereas fast pranayamas are more suitable for subjects with stable cardiovascular function ..."

"The presente study showed that the practice ANYB and BAW reduced the systolic and diastolic BP and systolic BP when people with hypertension performed the Purdue pegboard task (with better score after ANYB). Since the task requires dexterity and coordination, it also requires focusing. Focusing is known to be associated with sympathetic activation. Hence ANYB reduces BP but improves performance in a skilled motor task in people with hypertension."

"The results suggest that vagal activity increased during and after ANYB, which could have contributed to the decrease in BP and changes in the HRV."

"To conclude, this pilot study showed that the practice of slow breathing exercise (pranayama) on a regular basis attenuated the sympathetic tone of body in healthy volunteers, and that the changes began to appear in a short period of seven days ..."

"..it can be concluded from the present study that Mukh Bhastrika, practiced for a longer duration, has beneficial effects on the cardiovascular autonomic reactivity, and the study results can be widely applicable in day-to-day life, to all people from various social, environmental, cultural, and religious backgrounds ..."

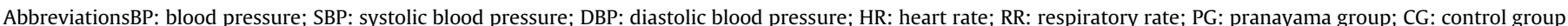

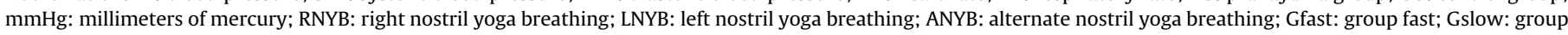

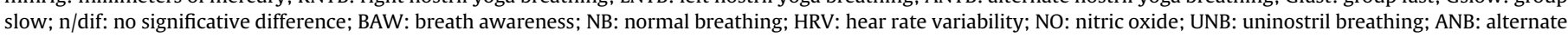
nostril breathing; CV: cardiovascular; CNP: chandra nadi pranayama.

\section{Discussions}

Existing reviews $[14,17,18]$ investigated the effect of yogic practices in general, making it difficult to understand what technique specific had promotes the effects found. The objective of this review was to investigate only studies that used pranayamas on BP. Were found 13 articles, nine of which emphasize the effects of pranayamas in reducing $\mathrm{BP}$.
Although selected studies use only breathing exercises, there is a wide variety of pranayamas described in ancient Yoga text (Hatha Yoga Pradipika) for specific purposes, such as increased concentration, relaxation, increased breathing capacity, etc., even with the objective to reduce blood pressure, the adopted pranayamas showed no similarities. Apparently, the pranayamas with slower rhythms and manipulation of the nostrils, mainly with breaths by the left, present better results when compared with the other 
types.

Five investigated the effect of practice for a few sessions [25-29] (1-12 weeks), including four showed significant reduction in BP, and just one not present positive results (smaller intervention time) [28].

The participants of seven [9,19-24] acute-effects studies had previous experience with Yoga or with breathing exercises. This may have contributed to the effectiveness of the intervention. We believe that unfamiliarity with exercise, can promote disconforts and tensions that would lead to acute physiological alterations that are contrary to the proposed objectives. While more prolonged practices can provide greater benefits in cardiovascular parameters by the process of learning and adaptation of the physiological mechanisms.

In all studies with control group [23,24,26-28], there were no significant differences in these groups, while the intervention group $[23,24,26,27]$ showed reductions for the main variables.

With regard the methodological quality of included studies, all were methodologically deficient, which reinforces the low quality of studies with Yoga, presenting biases as non-random distribution [9,10,19-22,24-26,29], lack of control group [9,10,19-22,25,29], no presence of blinded examiners [9,10,19-22,24-29], blood pressure measured using different protocols and not always presented clearly in the methods.

\subsection{Implications for clinical practice}

The pranaymas can play a role in the primary prevention of cardiovascular disease especially in patient populations with increased risk of cardiovascular disease but also in healthy participants. The pranayamas with slower rhythms and manipulation of the nostrils, mainly with breaths by the left, present better results when compared with the other types and should be the main pranayamas applied when the goal is to reduce blood pressure especially in hypertensive patients. However, the implications for clinical practice are limited by the low methodological quality of the included studies.

\subsection{Limitations}

We cannot guarantee that all relevant trials were located. Another limitation to this review is the overall risk of bias, as most studies suffer limitations of blinding patients, therapists and assessors to treatment conditions, lack of randomization. Moreover, this review included normotensive patients and patients with different conditions of hypertension. This review is further limited by the heterogeneity of intervention programmes regarding content, frequency and duration of the exercise.

\section{Conclusion}

Interventions with slow and alternate pranayamas appear to be effective to reduce blood pressure in normal and hypertensive patients. However, the evidence must be regarded as preliminary due to the heterogeneity of methodological quality, limited number of available RCTs and the differents pranayamas types. Methodological improvements are required so that we can get reliable results and to earning potential for the inclusion of pranayamas as a complement to pharmacological treatment.

\section{Disclosures}

This work was supported by Coordenação de Aperfeiçoamento de Pessoal de Nível Superior.

\section{Conflicts of interest}

No conflicts to declare.

\section{References}

[1] S. Basu, C. Millett, Social epidemiology of hypertension in middle-income countries determinants of prevalence, diagnosis, treatment, and control in the WHO SAGE study, Hypertension 62 (2013) 18-26.

[2] M.I. Schmidt, B.B. Duncan, JF. Hoffmann, L. Moura, D.C. Malta, R.M.S.V. Carvalho, Prevalência de diabetes e hipertensão arterial no Brasil baseada em inquérito de morbidade auto-referida, Brasil, 2006, Rev Saúde Pública 43 (Suppl. 2) (2009) 74-82.

[3] American College of Sports Medicine, Position stand: exercise and hypertension, Med. Sci. Sports Exerc 36 (2004) 533-553.

[4] G.V. Guimarães, E.G. Ciolac, V.O. Carvalho, V.M. d'́vila, L.A. Bortolotto, E.A. Bocchi, Effects of continuous vs, interval exercise training on blood pressure and arterial stiffness in treated hypertension, Hypertens. Res. 33 (2010) 627-632.

[5] E.G. Ciolac, High-intensity interval training and hypertension: maximizing the benefits of exercise? Am. J. Cardiovasc. Dis. 2 (2012) 102-110.

[6] D.R. Bueno, C.S.C. Rosa, J.S. Codogno, R.A. Fernandes, I.F. Freitas Jr., H.L. Monteiro, Physical activity level, comorbidities, and aging in hypertensive patients. Motriz, Rev. Educ. Física (Online) 19 (2013) S16-S24.

[7] B.C. Turi, J.S. Codogno, R.A. Fernandes, H.L. Monteiro, Physical activity, adiposity and hypertension among patients of public healthcare system, Rev, Bras. Epidemiol. 17 (2014) 925-937.

[8] K.U. Dhungel, V. Malhotra, D. Sarkar, R. Prajapati, Effect of alternate nostril breathing exercise on cardiorespiratory functions, Nepal Med. Coll. J. 10 (2008) 25-27.

[9] A.B. Bhavanani, Z. Sanjay, Madanmohan, Immediate effect of sukha pranayama on cardiovascular variables in patients of hypertension, Int. J. Yoga Ther. 21 (2011) 73-76

[10] A.B. Bhavanani, Sanjay Z. Madanmohan, Immediate effect of chandra nadi pranayama (left unilateral forced nostril breathing) on cardiovascular parameters in hypertensive patients, Int. J. Yoga 5 (2012) 108-111.

[11] J. Mizuno, H.L. Monteiro, An assessment of a sequence of yoga exercises to patients with arterial hypertension, J. Bodyw. Mov. Ther. 17 (2013) 35-41.

[12] S. Telles, S.K. Sharma, A. Balkrishna, Blood pressure and heart rate variability during yoga-based alternate nostril breathing practice and breath awareness, Med. Sci. Monit. Basic Res. 20 (2014) 184-193.

[13] P. Kupfer, Yoga Prático. Florianópolis: Dharma, 2001.

[14] H. Cramer, H. Haller, R. Lauche, N. Steckhan, A. Michalsen, G. Dobos, A systematic review and meta-analysis of yoga for hypertension, Am. J. Hypertens. 27 (2014) 1146-1151.

[15] P. Raghuraj, A.G. Ramakrishnan, H.R. Nagendra, S. Telles, Effect of two selected yogic breathing techniques on heart rate variability, Indian J. Physiol. Pharmacol. 42 (1998) 467-472.

[16] R.B. Ankad, A. Herur, S. Patil, G.V. Shashikala, S. Chinagudi, Effect of short-term pranayama and meditation on cardiovascular functions in healthy individuals, Heart Views 12 (2011) 58-62.

[17] M. Hagins, R. States, T. Selfe, K. Innes, Effectiveness of yoga for hypertension: systematic review and meta-analysis, Evidence-Based Complementary Altern. Med. (2013). http://dx.doi.org/10.1155/2013/649836.

[18] P. Posadzki, H. Cramer, A. Kuzdzal, M.S. Lee, E. Ernst, Yoga for hypertension: a systematic review of randomized clinical trials, Complementary Ther. Med. 22 (2014) 511-522.

[19] A.B. Bhavanani, Sanjay Z. Madnmohan, I.V. Basavaraddi, Immediate cardiovascular effects of pranava pranayama in hypertensive patients, Indian J. Physiol. Pharmacol. 56 (2012) 273-278.

[20] A.B. Bhavanani, M. Ramanathan, R. Balaji, D. Pushpa, Differential effects of uninostril and alternate nostril pranayamas on cardiovascular parameters and reaction time, Int. J. Yoga 7 (2014) 60-65.

[21] H.D. Critchley, A. Nicotra, P.A. Chiesa, Y. Nagai, M.A. Gray, L. Minati, L. Bernardi, Slow breathing and hypoxic challenge: cardiorespiratory consequences and their central neural substrates, PLoS One 10 (2015) e0127082.

[22] P. Raghuraj, S. Telles, Immediate effect of specific nostril manipulating yoga breathing practices on autonomic and respiratory variables, Appl. Psychophysiol. Biofeedback 33 (2008) 65-75.

[23] S. Telles, A. Yadav, N. Kumar, S. Sharma, N.K. Visweswaraiah, A. Balkrishna, Blood pressure and purdue pegboard scores in individuals with hypertension after alternate nostril breathing, breath awareness, and no intervention, Med. Sci. Monit. 19 (2013) 61-66.

[24] S. Telles, S.K. Sharma, A. Balkrishna, Blood pressure and heart rate variability during yoga-based alternate nostril breathing practice and breath awareness, Med. S. D. Monit. Basic Res. 20 (2014) 184-193.

[25] R. Adhana, R. Gupta, J. Dvivedi, S. Ahmad, The influence of the 2:1 yogic breathing technique on essential hypertension, Indian J. Physiol. Pharmacol. 57 (2013) 38-44.

[26] R. Goyal, H. Lata, L. Walia, M.K. Narula, Effect of pranayama on rate pressure product in mild hypertensives, Int. J. Appl. Basic Med. Res. 4 (2014) $67-71$. 
[27] V.K. Sharma, M. Trakroo, V. Subramaniam, M. Rajajeyakumar, A.B. Bhavanani, A. Sahai, Effect of fast and slow pranayama on perceived stress and cardiovascular parameters in young health-care students, Int. J. Yoga 6 (2013) 104-110.

[28] A.V. Turankar, S. Jain, S.B. Patel, S.R. Sinha, A.D. Joshi, B.N. Vallish, P.R. Mane, S.A. Turankar, Effects of slow breathing exercise on cardiovascular functions, pulmonar functions \& galvanic skin resistance in healthy human volunteers a pilot study, Indian J. Med. Res. 137 (2013) 916-921.

[29] S.G. Veerabhadrappa, V.S. Balijoshi, S. Khanapure, A. Herur, S. Patil, R.B. Ankad, S. Chinagudi, Effect of yogic bellows on cardiovascular autonomic reactivity, J. Cardiovasc. Dis. Res. 2 (2011) 223-227. 